\title{
Rajah Brooke's Birdwing
}

\section{F. Owen}

The growing trade in rare butterflies threatens some relatively common species as well as rare ones, notably the conspicuous Rajah Brooke's birdwing. The author describes some of the traders' activities and asks for information.

Rajah Brooke's birdwing, a beautiful iridescent butterfly still quite common in Malaysia, is being collected on an unprecedented scale. Along with other showy tropical butterflies it could easily be reduced to the point of extinction.

In recent years there has been an enormous increase in world trade in dead butterflies, and, contrary to what might be expected, it is often the common, not the rare, species that are most threatened by collectors and dealers. Hundreds of back-street 'antiques' shops in Britain have started selling butterflies, and, although no reliable figures are available, there seems little doubt that this is a growth industry. Expensively produced catalogues, some in full colour, alone attest to the volume of trade and the size of the profits. One dealer claimed (Sunday Times, January 23rd 1972) that Rajah Brooke's birdwing is caught in Malaysia and offered at prices per thousand, but that no 'legitimate' butterfly dealer in Britain would buy specimens acquired in this way. Nevertheless it appears in almost all catalogues and is one of the species most frequently seen in shops. In any case 'legitimate' in this context has no legal meaning, for Britain has no restrictions on the import and sale of dead butterflies.

The birdwing butterflies belong to the swallowtail family. The brilliantly coloured males are easily collected as they feed from damp soil contaminated with mammal (including human) urine; the less brilliant females are more difficult as they tend to fly in the tree-tops. A male Rajah Brooke's usually sells in Britain for less than $£ 1$, depending on its condition, whether mounted or in 'papers', or in a glass-fronted frame; rare birdwing species, which are confined to small islands in the Far East, sell for up to $£ 100$ a pair.* Recent reports from dealers in the Far East, who supply dealers in Britain, the USA and Japan, suggest that birdwings as a group are becoming difficult to obtain in quantity and that supply cannot match demand. This has put prices up.

\section{Butterfly workshops}

In south-east Asia and South America local people collect and sell butterflies for relatively small sums to dealers in their own country. Taiwan has long been known as the most important supplier to the world market. A report in Wildlife (August 1974) describes workshops in Puli: 'I was astonished', he writes, 'at the scale of their operations. There are lines of tables at which women are seated, with up to 50 in a single labour force. They work from 8 a.m. to 10 p.m. and each workshop processes about 2000 butterflies a day. On the tables there are piles of butterflies of the more common species, 10,000 or so to the pile. The most usual process consists of detaching the wings, (and) pasting them on to simulated paper bodies. ... The actual bodies are thrown

* Other observers quote prices up to $£ 600$. Editor. 
into boxes on the floor and are used as pig food'. (See also 'Wildlife in Taiwan', by Philip Wayre, Oryx $10,1$.

Butterfly wings from Taiwan and the iridescent blue wings of South American morpho butterflies are often used to decorate trays and for 'butterfly jewelry', which can be bought all over the world. They are often to be found in antique shops in Britain, and they can be ordered from dealers by mail. The catalogue of Worldwide Butterflies, of Sherborne, Dorset, offers 'real butterfly jewelry. The unique iridescent blue of this South American morpho butterfly jewelry is something which cannot be imitated. A full range can be seen in our Brighton and Lyme Regis showrooms'.

Some dealers pretend to be more conservation-minded. Saruman of Tunbridge Wells, who have a magnificent catalogue in colour, with information (not always accurate) about the butterflies' natural history, stress 'the importance of conserving butterflies for study, and for the pleasure they give. ...', but the illustrations, showing row after row of exotic tropical butterflies for sale, some of them rare, do not suggest they are serious.

Others are more subtle. Another firm, which offers a male Rajah Brooke's birdwing mounted in a glass-fronted frame for $£ 5.95$, has inserted as a footnote in its colour catalogue (in very small print): 'Bred in captivity, freed in jungles to preserve species. Some die in captivity and are shown here'. The specimens shown include species from Peru, Malaysia, and Madagascar, and we are in effect asked to imagine that this firm, based in North Wales, arranges regular shipments of live butterflies to the precise localities where they occur naturally. I simply do not believe them.

Dealers in Britain solicit collectors in the field for specimens, and buy directly from local dealers in a wide variety of countries, especially in the Far East and South America. Beautiful Butterflies, of Wolverhampton, make no secret about this. 'Hundreds of specimens are received from abroad every year', they say, 'and the wonderful colours and patterns of some species have to be seen to be believed'.

Dealers often claim that the bulk of the specimens they offer for sale come from old collections. No doubt substantial numbers are acquired in this way, but the main trade is in butterflies freshly taken both in Britain and overseas. Dealers will undertake to supply recently taken specimens of some of Britain's rarest butterflies; indeed they are prepared to obtain almost anything - at a price. The specimens sold rarely have data labels attached to them, so it is impossible to say exactly where and when a butterfly was collected, but the style of pinning and the freshness of many specimens strongly suggest that they are recently taken.

\section{Who buys?}

The extravagant catalogues produced by dealers suggest a brisk business, but it is not easy to find out who the buyers are. They are not the knowledgeable butterfly enthusiasts. Experienced collectors and amateur naturalists do not usually pose a serious threat, and I would not wish to see legislation forbidding butterfly collecting altogether, although I believe the time has come to prohibit collecting of some of the rarer British species, such as the Glanville fritillary.* I think that most specimens and certainly most decorative items

* The large blue is now protected under the Wild Creatures \& Wild Plants Protection Act of 1975. Editor. 
are bought by people with little or no interest in natural history. Seaside towns and tourist centres seem to have a high frequency of shops offering butterflies for sale, and it may be that people buy them in much the same way as they buy sea shells, as a reminder of a pleasant holiday or as a gift.

Some people may first acquire the urge to possess their own specimens as a result of a visit to a museum. Many of the displays, including the one in the Natural History Museum in London, are designed to show off the butterflies' brilliant colours and large size. I would like to see museums arrange exhibits in such a way as to convey the conservation message, as they do with birds and mammals; the time has come to include butterflies.

\section{Two misconceptions}

It is widely held that despite the volume of trade there is no danger to butterfly populations, that, for instance, there are still plenty of butterflies in Taiwan. This viewpoint ignores the essential features of exponential processes: collecting and killing can go on year after year with no obvious signs of depletion, until, quite suddenly, a species becomes rare and perhaps extinct. This is what I call the 'passenger pigeon effect'. Not until it is too late does it become apparent what is happening. There is little doubt in my mind that if a relatively common species like Rajah Brooke's birdwing continues to be exploited at the present rate it will suddenly become very rare, and perhaps extinct.

It is also commonly believed that most butterfly species have an excess of males that can be 'harvested'. In fact, for the majority of species, the sex ratio is $1: 1$, but because of their behaviour the males are more frequently encountered by collectors. (There are a few exceptions in which there is an excess of females.) In West Africa I have seen up to fifty individuals of twelve swallowtail species feeding at damp soil, every one a male, and extremely easy to net. Dealers use this apparent excess of males to defend their trade, arguing that since a male is capable of fertilising more than one female it is reasonable to crop the males. But in butterflies, as in all animals, the sex ratio is determined by natural selection: nature does not produce an excess of one sex. The belief seems to originate from a paper published in the Proceedings of the 13th International Congress of Entomology (Moscow, 1968), in which J. C. M. Carvalho and $\mathrm{O}$. H. H. Mielke defend the butterfly trade in Brazil, amounting in the 1960 s to more than fifty million specimens a year, with figures that purport to show ten times, even several hundred times as many males as females in many species. Although not stated the figures were almost certainly based on male-biased field collections. One of the authors was at the time President of the Brazilian Foundation for the Conservation of Nature, and it is hardly astonishing that his statements should be taken as authoritative by dealers.

\section{What can be done?}

The most urgent need is for more information on the extent and volume of the butterfly trade so that action can be planned. For some years I have collected dealers' catalogues and addresses, and I have started listing shops that sell specimens. I would, therefore, like to invite readers to provide me with information: the names of dealers and shops, what is being sold and the prices asked.

Dr Owen's address is 66 Scraptoft Lane, Leicester.

Since this article was written (1974) some dealers have joined forces, so some of the companies mentioned may not now be in business. 